Г. С. Россихіна, В. Я. Попов

Дніпропетровський національний університет ім. Олеся Гончара

\title{
СИСТЕМАТИЗАЦІЯ ТА ВДОСКОНАЛЕННЯ МЕТОДОЛОГІЧНОГО ЗАБЕЗПЕЧЕННЯ ДОСЛІДЖЕННЯ ПОСУХОСТІЙКОСТІ РОСЛИН
}

\begin{abstract}
Запропоновано підхід до підвищення рівня формалізації процесу дослідження стійкості рослин до посухи на прикладі математичного моделювання даного процесу стосовно деяких зернових культур. Як ключові напрямки вибрано забезпечення можливості нормованого варіювання рівнем посухи, визначення якості контрольних зразків рослин, планування експерименту, розробку та дослідження ефективного методу визначення посухостійкості рослин.
\end{abstract}

\author{
G. S. Rossihina, V. J. Popov \\ Oles' Gonchar Dnipropetrovsk National University
}

\section{SYSTEMATISATION AND IMPROVEMENT OF METHODOLOGICAL COVERAGE OF THE RESEARCH OF PLANTS DROUGHT-RESISTANCE}

An approach to enhancing the level of formalisation of the investigations of plants' resistance to drought is suggested. The approach is demonstrated on example of grain plants by using mathematical simulation. The approach gives a chance to standardize variation of the level of drought, to estimate the quality of plant control specimens, to plan the experiment and to create an effective method of assessment of the plants' resistance to drought.

\section{Вступ}

У загальній проблемі дослідження адаптивних можливостей рослин до комбінованого впливу комплексу стрес-факторів навколишнього середовища значне місце посідають питання оцінки посухостійкості зернових культур $[2-4 ; 11 ; 13 ; 14]$. Посухи призводять до суттєвих втрат рослинницької продукції [6; 7; 9]. Тому методологічне забезпечення всебічного дослідження біологічної та агрономічної стійкості рослин до посухи - завдання державної важливості. Безпосередня оцінка рівня агрономічної стійкості рослин до посухи - тривале та трудомістке завдання. Тому в селекційній та інтродукційній практиці широко використовуються непрямі лабораторні методи оцінки біологічної стійкості за фізіологічними, анатомічними, морфологічними та біохімічними показниками. До відомих відносяться, наприклад, непрямі методи оцінки посухостійкості зернових культур за оптичною густиною екстрактів листя, ростовою реакці$€ ю$, ступенем відновлення мітотичної активності меристеми пагона після підсушування, величиною енергетичного заряду аденозинфосфатної системи, відносним лінійним приростом пагонів і коренів після підсушування, інтенсивністю виділення електролітів флаговими листками та інші $[5 ; 10]$. Мають місце випадки застосування біохімічних та біофізичних методів, які передбачають визначення електропровідності тканин, а також активності фосфорорганічних сполук та ферментів [5; 12]. 
Реалізація перелічених вище відомих методів допускає несанкціоновану появу артефактів у процесі проведення модельних експериментів у зв'язку з недостатньо високим рівнем формалізації процесів непрямої оцінки посухостійкості зернових культур. Це пояснюється не лише слабкою кореляцією зі справжньою посухостійкістю покладених в основу ряду методів критеріїв, а і необхідністю виконання таких, що не піддаються нормалізації, процедур, як зміна та регулювання ступеня підсушування пагонів і коріння, визначення факту загибелі тканин при перегріві поживних розчинів, оцінка однаковості розвитку та непошкодженості флагових листків дослідних рослин тощо [10]. Наведений недолік відомих методів $є$ причиною відсутності можливості застосування математичного моделювання у процесі дослідження стійкості рослин до комбінованої дії посухи та ксенобіотиків і, як наслідок, суттєвого зниження достовірності результатів експериментів, а також неможливості в ряді випадків забезпечення їх повторності.

Тому мета роботи - підвищення рівня формалізації процесу дослідження посухостійкості рослин за рахунок систематизації та вдосконалення відповідного методологічного забезпечення на прикладі математичного моделювання процесу визначення посухостійкості зернових культур.

\section{Опис запропонованої методики}

До ключових напрямків підвищення ступеня формалізації процедури оцінки посухостійкості рослин доцільно віднести забезпечення можливості нормованого варіювання рівнем посухи, визначення якості контрольних зразків рослин, планування експерименту, а також розробку та дослідження ефективного лабораторного методу визначення посухостійкості. При цьому під ефективністю розуміється відповідність запропонованого методу діагностики посухостійкості рослин загальним вимогам до диференційної здатності, достовірності оцінки, придатності для точного інструментального вимірювання, технічної бази, ступеня трудоємності, тривалості оцінки та пропускної здатності. Отримані результати досліджень створюють реальні передумови для суттєвого підвищення достовірності оцінок стійкості зернових культур до комбінованого екзогенного впливу посухи, жари, залишкових грунтових гербіцидів, важких металів та інших полютантів. Для простоти викладення в даному повідомленні як чинник навколишнього середовища розглянута посуха.

Певні рівні посухи імітували шляхом зневоднення протоплазми клітин у процесі витримки проростків дослідної зернової культури протягом заданого часу в розчині неелектроліту (дистильованій воді) з відповідним осмотичним тиском $(P)$. Потрібні рівні осмотичного тиску забезпечували застосуванням відповідних концентрацій сахарози [8]. Визначення чітко нормалізованої відповідності між рівнями посухи та осмотичного тиску у прикореневій зоні проблематичне у зв'язку із труднощами формалізації цього процесу. Враховуючи можливі відмінності між біохімічними механізмами реакцій рослин на вплив природної посухи та осмотичного тиску, наведений спосіб зневоднення тест-об' єктів можна рекомендувати для використання переважно при реалізації методів порівняльної оцінки посухостійкості.

Використання в експерименті контрольних рослин сумнівної чистоти, наприклад, підлеглих у минулому інтенсивному впливу певних стрес-факторів, дає як правило, неправильні результати досліджень. Для особливо відповідальних досліджень у роботі запропоновано підхід до оцінки толерантності зернових культур до впливу стрес-факторів з урахуванням кількісного визначення індексу аутентичності контрольної рослини [1]. При цьому для вибіркової сукупності контрольних рослин, що беруть 
участь в експерименті, будується крива розподілу за індексом корелятивного росту пагона та коріння, визначається коефіцієнт кореляції емпіричної та еталонної кривої, який і використовується як індекс аутентичності контрольної рослини. При слабкій та середній відповідності контрольної рослини еталонним вимогам (індекс аутентичності менше 0,7) рослина виключається з експерименту і замінюється культурою 3 вищим ступенем чистоти. Експериментальним шляхом отримана біолого-статистична модель еталонної кривої розподілу, а також запропонована формула індексу корелятивного росту пагона та коріння для зернових культур [1].

При побудові експерименту віддано перевагу статистичним методам планування для вивчення факторних залежностей.

Процедура оцінки посухостійкості зернових культур запропонованим методом включає таку послідовність операцій: вибір мішеней інгібіторної дії фактора $P$ на клітинному та організмовому рівнях, визначення параметрів реакції мішеней на вплив стрес-фактора, зняття емпіричних залежностей параметрів реакції мішені від варійованого в установлених межах рівня фактора $P$, розробка математичної моделі залежності параметрів реакції від $P$, формування приватних критеріїв оцінки посухостійкості рослини на клітинному та організмовому рівнях, формування комбінованого критерію оцінки посухостійкості рослини в цілому, власне оцінка посухостійкості.

Як мішень інгібувальної дії фактора $P$ на організмовому рівні обрано видільну активність кореневої системи, на клітинному рівні - основні ферменти системи антиоксидантного захисту рослин. Як параметр реакції мішені на організмовому рівні обрано модуль зсуву концентрації водневих іонів у прикореневій зоні, на клітинному рівні - модуль зсуву ферментативної активності за час дії фактора $P$. Індекс посухостійкості рослин $I_{n c}$ визначався за наступною формулою:

$$
I_{n c}=K_{K}=\frac{\kappa_{p H^{+}} K_{A \Phi}}{2},
$$

де $K_{\kappa}$ - комбінований критерій оцінки посухостійкості; $K_{p H}=\frac{|\Delta p H|_{\kappa}}{|\Delta p H|_{\partial}}=\frac{a+b P_{H}}{a+b P_{3}}-$ частковий критерій оцінки посухостійкості на основі модуля зсуву концентрації водневих іонів $|\Delta p H|$ у прикореневій зоні за час витримки рослини у розчині із заданим осмотичним тиском; $K_{A \Phi}=\frac{|\Delta A \phi|_{\kappa}}{|\Delta A \phi|_{\partial}}=\frac{c+d P_{H}}{c+d P_{3}}-$ частковий критерій оцінки посухостійкості на основі модуля зсуву ферментативної активності клітин кореневої системи $|\Delta A|_{\Phi}$ за час витримки рослини в розчині із заданим рівнем осмотичного тиску; $|\Delta p H|_{\kappa},|\Delta p H|_{\partial}$ - модуль зсуву концентрації водневих іонів у прикореневій зоні контрольної та досліджуваної рослини відповідно; $\left|\Delta A_{\Phi}\right|_{\kappa},\left|\Delta A_{\Phi}\right|_{\partial}$ - модуль зсуву ферментативної активності клітин кореневої системи контрольної та досліджуваної рослин відповідно; $P_{t}$ - нормальний осмотичний тиск, атм.; $P_{3}$ - заданий підвищений осмотичний тиск, атм.; $a, b-$ параметри рівняння, що визначають співвідношення між концентрацією водневих іонів і осмотичним тиском у розчині з електролітом; $c, d$ - параметри рівняння, що визначають співвідношення між ферментативною активністю й осмотичним тиском у розчині з електролітом.

Запропонований метод визначення посухостійкості рослин апробований у процесі оцінки посухостійкості проростків кукурудзи (Zea mays L.) гібриду Кадр 267 MB i пшениці (Triticum durum L.) сорту Лада. Вибіркова сукупність насіння досліджуваних 
зернових культур пророщувалася в нормальних умовах протягом 8 діб на дистильованій воді. Потім отримана сукупність проростків для кожної культури розподілялася на групи, кількість яких відповідала наступному варіаційному рядові рівнів осмотичного тиску: 1, 5, 10, 15 атм. Кількість проростків у кожній групі - 20, кількість повторень дослідів - 4. Ці групи проростків розміщено в посудинах із розчинами сахарози, концентрації якої відповідали наведеному вище варіаційному ряду рівнів осмотичного тиску. Витримка проростків у розчинах із заданими рівнями осмотичного тиску склала 2 доби. До та після розміщення та витримки проростків у розчинах 3 осмотичним тиском вимірювали відповідні показники експерименту, що забезпечують визначення величини модуля зсуву основних властивостей мішеней інгібувальної дії посухи. Основні проміжні та кінцеві результати синтезу комбінованого критерію оцінки посухостійкості рослин і власне оцінки індексу посухостійкості наведені в таблицях 1 та 2.

Таблиия 1

Синтез комбінованого критерію оцінки посухостійкості кукурудзи та результати оцінки

\begin{tabular}{|c|c|c|c|c|c|c|c|c|}
\hline \multirow{2}{*}{\multicolumn{2}{|c|}{$\begin{array}{l}\text { Варіан- } \\
\text { ти мі- } \\
\text { шеней }\end{array}$}} & \multirow{2}{*}{$\begin{array}{l}\text { Рівняння залежностей } \\
\text { властивостей мішеней } \\
\text { від осмотичного тиску }\end{array}$} & \multirow[b]{2}{*}{$K_{p H}$} & \multirow[b]{2}{*}{$K_{A \Phi}$} & \multicolumn{4}{|c|}{$I_{\Pi C}$} \\
\hline & & & & & $\begin{array}{c}P= \\
1 \text { атм. }\end{array}$ & $\begin{array}{c}P= \\
5 \text { атм. }\end{array}$ & $\begin{array}{c}P= \\
10 \text { aтм. }\end{array}$ & $\begin{array}{c}P= \\
15 \text { aтм. }\end{array}$ \\
\hline \multirow{4}{*}{1} & $n H$ & $\Delta p H_{1}^{\prime}=0,793+0,099 \mathrm{P}$ & 0,892 & & \multirow{4}{*}{1} & \multirow{4}{*}{0,410} & \multirow{4}{*}{0,280} & \multirow{4}{*}{0,215} \\
\hline & & $\alpha=0,020$ & $0,793+0,099 P$ & & & & & \\
\hline & \multirow{2}{*}{$A_{K}$} & $\Delta A_{K !}^{\prime}=0,075+0,181 \mathrm{P} ;$ & \multirow{2}{*}{-} & 0,106 & & & & \\
\hline & & $r=0,990 ; \alpha=0,014$ & & $-0,075+0,181 P$ & & & & \\
\hline \multirow{4}{*}{2} & $n H$ & $\Delta p H_{1}^{\prime}=0,793+0,099 \mathrm{P}$ & 0,892 & & \multirow{4}{*}{1} & \multirow{4}{*}{0,497} & \multirow{4}{*}{0,331} & \multirow{4}{*}{0,251} \\
\hline & & $\mathrm{r}=0,980 ; \alpha=0,020$ & $0,793+0,099 P$ & & & & & \\
\hline & \multirow{2}{*}{$A_{\Pi}$} & $\Delta A_{\Pi !}^{\prime}=0,228+0,307 \mathrm{P}$ & \multirow{2}{*}{-} & 0,535 & & & & \\
\hline & & $r=0,997 ; \alpha=0,022$ & & $0,228+0,307 P$ & & & & \\
\hline \multirow{4}{*}{3} & $n H$ & $\Delta p H_{1}^{\prime}=0,793+0,099 \mathrm{P}$ & 0,892 & & \multirow{4}{*}{1} & \multirow{4}{*}{0,723} & \multirow{4}{*}{0,538} & \multirow{4}{*}{0,429} \\
\hline & & $r=$ & $0,793+0,099 P$ & & & & & \\
\hline & \multirow{2}{*}{$A_{\text {СОД }}$} & $\triangle A_{\text {СодІ }}=6,636+0,578 \mathrm{P} ;$ & \multirow{2}{*}{-} & 7,223 & & & & \\
\hline & & $r=0,992 ; \alpha=0,008$ & & $6,636+0,587 P$ & & & & \\
\hline
\end{tabular}

Примітки: ' $\Delta p H_{\mid}^{\prime},{ }_{i} \Delta A_{K}^{\prime},{ }_{i}, \Delta A_{\Pi \mid}^{\prime},{ }_{i} \Delta A_{\text {Сод; }}$ - модулі зсуву активності водневих іонів, каталази, пероксидази та супероксиддисмутази відповідно за час перебування проростків у розчинах із підвищеним осмотичним тиском; варіанти мішеней 1, 2, 3 - каталаза, пероксидаза та супероксиддисмутаза відповідно; $K_{p H}$, $K_{A \Phi}$ - часткові критерії оцінки посухостійкості на основі модуля зсуву концентрації водневих іонів $|\Delta p H|$ та ферментативної активності клітин $|\Delta A|_{\Phi}$ відповідно у прикореневій зоні за час витримки рослини; $I_{\Pi C}$ - індекс посухостійкості рослин; $\mathrm{P}$ - осмотичний тиск, атмосфер.

Із таблиць видно, що диференціювальна здатність визначення індексу посухостійкості за рахунок модулів зсуву видільної активності кореневої системи й активності супероксиддисмутази значно вища порівняно з варіантами комбінації видільної активності кореневої системи з каталазою або пероксидазою. Це пов'язано 3 тим, що комбінація видільної активності кореневої системи з активністю супероксиддисмутази відіграє вагомішу роль у метаболізмі рослин, ніж комбінація видільної активності кореневої системи $з$ активністю каталази та пероксидази, тому вона надійніше захищена механізмами забезпечення стійкості до дії стрес-факторів. 
Синтез комбінованого критерію оцінки посухостійкості пшениці та результати оцінки

\begin{tabular}{|c|c|c|c|c|c|c|c|c|}
\hline \multirow{2}{*}{\multicolumn{2}{|c|}{$\begin{array}{l}\text { Варіанти } \\
\text { мішеней }\end{array}$}} & \multirow{2}{*}{$\begin{array}{l}\text { Рівняння залежностей } \\
\text { властивостей мішеней } \\
\text { від осмотичного тиску }\end{array}$} & \multirow[b]{2}{*}{$K_{p H}$} & \multirow[b]{2}{*}{$K_{A \Phi}$} & \multicolumn{4}{|c|}{$I_{\Pi C}$} \\
\hline & & & & & $\begin{array}{c}P= \\
1 \text { aтм. }\end{array}$ & $\begin{array}{c}P= \\
5 \text { aтм. }\end{array}$ & $\begin{array}{c}P= \\
10 \text { aTм. }\end{array}$ & $\begin{array}{c}P= \\
15 \text { aTM. }\end{array}$ \\
\hline \multirow{4}{*}{1} & $p H$ & $\Delta p H_{1}=0,793+0,099 \mathrm{P}$ & 0,892 & & \multirow{4}{*}{1} & \multirow{4}{*}{0,410} & \multirow{4}{*}{0,280} & \multirow{4}{*}{0,215} \\
\hline & & $r=$ & $0,793+0,099 P$ & & & & & \\
\hline & \multirow{2}{*}{$A_{K}$} & \multirow{2}{*}{$\begin{array}{c}\qquad \Delta A_{K}^{\prime}=-0,075+0,181 \mathrm{P} \\
r=0,990 ; \alpha=0,014\end{array}$} & \multirow{2}{*}{ - } & 0,106 & & & & \\
\hline & & & & $-0,075+0,181 P$ & & & & \\
\hline \multirow{4}{*}{2} & $n H$ & $\Delta p H_{1}=0,793+0,099 \mathrm{P}$ & 0,892 & & \multirow{4}{*}{1} & \multirow{4}{*}{0,497} & \multirow{4}{*}{0,331} & \multirow{4}{*}{0,251} \\
\hline & & & $0,793+0,099 P$ & & & & & \\
\hline & \multirow{2}{*}{$A_{\Pi}$} & \multirow{2}{*}{$\begin{array}{c}\left\langle\Delta A_{\Pi_{1}^{\prime}}^{\prime}=0,228+0,307 \mathrm{P}\right. \\
r=0,997 ; \alpha=0,022\end{array}$} & \multirow{2}{*}{-} & 0,535 & & & & \\
\hline & & & & $0,228+0,307 P$ & & & & \\
\hline \multirow{4}{*}{3} & $n H$ & $\Delta p H_{1}^{\prime}=0,793+0,099 \mathrm{P}$ & 0,892 & -5 & \multirow{4}{*}{1} & \multirow{4}{*}{0,723} & \multirow{4}{*}{0,538} & \multirow{4}{*}{0,429} \\
\hline & & $r=0,980 ; \alpha=$ & $0,793+0,099 P$ & & & & & \\
\hline & \multirow{2}{*}{$A_{\text {Сод }}$} & $\triangle A_{\text {Соді }}^{\prime}=6,636+0,578 \mathrm{P}$ & \multirow{2}{*}{-} & 7,223 & & & & \\
\hline & & & & $6,636+0,587 P$ & & & & \\
\hline
\end{tabular}

Примітки: див. табл. 1.

\section{Висновки}

Використання запропонованого підходу у практиці лабораторних експериментів, пов'язаних із діагностикою рівня стійкості переважно зернових культур до посухи, забезпечує (за рахунок підвищення рівня формалізації послідовності операцій) суттєве зниження кількості артефактів. При проведенні експериментів і підвищенні ступеня достовірності оцінок стійкості досягається підвищення ефективності високовартісної селекційної та інтродукційної практики у польових умовах.

\section{Бібліографічні посилання}

1. Вінниченко О. М. Спосіб оцінки стійкості рослин до екзогенного впливу ксенобіотиків / О.М.Вінниченко, В. Я. Попов. Деклараційний патент на винахід № 69970А, Бюл. № 9, 2004.

2. Григорюк І. П. Аденозинфосфатна система та посухостійкість рослин // Физиология и биохимия культурных растений. - 2001. - Т. 33, № 3. - С. 199-207.

3. Григорюк І. П. Ріст пшениці і кукурудзи в умовах посухи та його регуляція / І. П. Григорюк, О. І. Жук. - К. : Науковий світ, 2002. - 118 с.

4. Мартон Ч. Л. Засухоустойчивость гибридов кукурузы / Ч. Л. Мартон, Т. Сунди, Б. Дерффи // Физиология и биохимия культурных растений. - 2002. - Т. 34, № 1. - С. 17-20.

5. Методы оценки устойчивости растений к неблагоприятным условиям среды / Под ред. Г. В. Удовенко. - Л. : Колос, 1976. - 318 с.

6. Нижник Т. П. Інтенсивність пероксидного окислення ліпідів і активність антиоксидантних ферментів у листках картоплі за дії посухи та полістимуліну К / Т. П. Нижник, І. П. Григорюк, Л. М. Михальські // Український біохімічний журнал. - 2004. - Т. 76, № 1. - С. 130-135.

7. Пустовойтова Т. Н. Основные направления в изучении влияния засухи на физиологические процессы у растений / Т. Н. Пустовойтова, В. Н. Жолкевич // Физиология и биохимия культурных растений. -1992 . - Т. 24, № 1. - С. 14-26.

8. Равич-Щербо М. И. Физическая и коллоидная химия / М. И. Равич-Щербо, В. В. Новиков. М. : Высшая школа, 1975. - С. 37-43. 
9. Січкар В. І. Фізіологічна реакція сортів сої на посуху і підвищену температуру / В. І. Січкар, А. К. Ляшок, В. М. Мусич // Фізіологія та біохімія культурних рослин. - 2001. - Т. 33, № 6. C. 497-503.

10. Современные методы исследования и оценки засухо- и жаростойкости растений / И. А. Григорюк, В. И. Ткачев, С. В. Савинская, Н. Н. Мусиенко. - К. : Науковий світ, 2003. - С. 109-112.

11. Шадчина Т. М. Влияние почвенной засухи и засоления на фотосинтез и параметры индукции флуоресценции листьев яровой пшеницы / Т. М. Шадчина, В. А. Стороженко, Д. А. Лихолат // Физиология и биохимия культурных растений. - 2004. - Т. 36, № 6. - С. 520-527.

12. Шматько И. Г. Устойчивость растений к водному и температурному стрессам / И. Г. Шматько, И. А. Григорюк, О. Е. Шведова. - К. : Наукова думка, 1989. - 224 с.

13. Haldimann P. Effects of changes in growth temperature on photosynthesis and carotenoids composition in Zea mays leaves // Physiol. Plant. - 1996. - Vol. 97, N 3. - P. 554-562.

14. Sayed O. H. Effects of temperature on growth, morphology and photosynthesis in wheat // Biol. Plant. - 1995. - Vol. 37, N 1. - P. 49-55.

Надійшла до редколегї 30.10.2008 